\title{
Analisis Penentuan Tarif Jasa Transportasi Udara Rute Kediri - Jakarta di Bandar Udara Kediri
}

\author{
Kurnia Hadi Putra', Fenti Nur Azizah ${ }^{2}$ \\ 1,2 Jurusan Teknik Sipil, FTSP, Institut Teknologi Adhi Tama Surabaya \\ Email: ${ }^{1}$ kurnia_putra@itats.ac.id, ${ }^{2}$ fentiazizah64@gmail.com
}

\begin{abstract}
Kediri Airport has been developed by Gudang Garam Ltd and Angkasa Pura I Ltd since 15April 2020. This airport will open the access of surrounding areas such as Tulung Agung, Blitar, Ponorogo, Trenggalek, Madiun, and Magetan. To know the tariff value for the flight of Kediri-Jakarta route, the researcher conducted value analyses using ATP (Ability To Pay) and WTP (Willingness To Pay) as well as tariff analysis based on the Government Regulation No.51 Year 2014. Meanwhile, the methods used to count ATP value wasHousehold Budget and the one for calculating WTP wasState Preference.The result of ATP (Ability To Pay) earned averagely IDR 361,000,00, while WTP (Willingness To Pay) gained averagely IDR 784,000,00. This sort of condition was named Captive Riders, meaning that the willingness to pay for transportation service was higher than the ability to pay for transportation service. The calculation using the Government Regulation No. 51 in 2014 obtained tariff IDR 1.204.753,50, in the other words, this value was more than the willingness and ability to pay of passengers who want to use the transport service of Kediri Airport. Accordingly, the subsidy from government is necessary.
\end{abstract}

Keywords: Kediri Airport, ATP (Ability To Pay), WTP (Willingness To Pay), Government Regulation No.51 in 2014

\begin{abstract}
Bandara Kediri yang akan dibangun oleh PT Gudang Garam dan PT Angkasa Pura I (Persero), yang saatini sedang dalam pembangunan mulai sejk tanggal 15 April 2020. Bandar Udara Kediri mempunyai rencana akan membuka akses wilayah sekitar sepert Tulung Agung, Blitar, Ponorogo, Trenggalek, Madiun, dan Magetan. Untuk mengetahui nilai tarif yang sesuai untuk penerbangan rute Kediri-Jakarta maka dibutuhkan analisis nilai ATP (Ability To Pay) dan WTP (Willingness To Pay) dan juga analisis tarif menurut Peraturan Pemerintah No.51 Tahun 2014. Metode yang digunakan untuk perhitungan nilai ATP adalah Household Budget dan WTP adalah State Preference. Hasil dari nilai rata-rata ATP (Ability To Pay) sebesar Rp. 361.000,00 dan nilai rata-rata WTP (Willingnuess To Pay) sebesar Rp. 784.000,00 dimana kondisi ini disebut Captive Riders yang berarti kemauan membayar jasa transportasi lebih besar dibandingkan kemampuan membayar jasa transportasi. Untuk hasil perhitungan menggunakan peraturan pemerintah No. 51 Tahun 2014 yaitu sebesar Rp. 1.204.753,50 dimana hasil nilai tersebut lebih besar dibandingkan dengan kemampuan dan kemauan calon penumpang Jasa Transportasi Bandar Udara Kediri. Maka perlu diberlakukan subsidi dari pemerintah.
\end{abstract}

Kata kunci: Bandar Udara Kediri, ATP (Ability To Pay), WTP (Willingness To Pay), Peraturan Pemerintah No.51 Tahun 2014

\section{Pendahuluan}

Transportasi adalah proses berpindah atau pergerakan barang dan atau manusia dari tempat asal ke tempat tujuan. Secara harfiah transportasi ialah suau aktivitas memindahkan sesuatu (manusia/barang) dari ke tempat awal ke tempat lainnya [3]. Untuk saat ini jasa transportasi berguna untuk memenuhi kebutuhan, dan saat ini juga tranportasi menjadi bagian penting bagi masyarakat. Kota Kediri adalah suatu kota yang terletak di sebuah Provinsi Jawa Timur yang terletak di sebelah 
selatan kota Surabaya. Kota Kediri memiliki luas $63,40 \mathrm{~km}^{2}$ yang terbelah oleh sungai Brantas. Kota Kediri berada pada jalur transportasi yang menghubungkan beberapa kota di jawa timur seperti Surabaya, dengan tulung agung, Surabaya dengan malang dan nganjuk [2]. Bandara Kediri yang akan di bangun Oleh PT Gudang Garam dan PT Angkasa Pura I (Persero) yang saat ini sedang dalam pembangunan yang mulai sejak tanggal 15 April 2020. Bandara Kediri mempunyai rencana akan membuka akses wilayah sekitar seperti Tulung Agung, Blitar, Ponorogo, Trenggalek, Madiun dan Magetan. Bandara kediri didirikan dengan menerapkan konsep multi-airport. Adanya bandara ini dimaksudkan agar menjadi alternatif fungsi untuk Bandara Juanda Surabaya dalam pengurangan daya tampung para pengguna jasa pesawat terbang. Hal tersebut dikarenakan daya tampung Bandara Juanda Surabaya sudah mencapai batas maksimum, kapasitas sebenarnya yaitu hanya 6 juta penumpang/tahun. Namun seriap tahunnya mengalami perlonjakan setiap tahunnya. Bandara Internasional Juanda melayani hampir 1,6 juta penumpang atau perhari rata-rata mencapai sekitar 53.400 orang. Kabupaten Kediri menjadi tempat pembangunan Bandar Udara Kediri. Bandar Udara Kediri ini akan memiliki konsep dengan Bandar Udara Kelas International [2].

Ability To Pay (ATP) yaitu kesanggupan bagi penumpang atau yang menggunakan jasa untuk melakukan pembayaran suatu jasa yang telah diperoleh berdasarkan pendapatan orang tersebut. Penyebab-penyebab yang dapat mempengaruhi ATP yaitu besar penghasilan yang diterima, kebutuhan akan tranportasi, seringnya melakukan perjalanan, total pengeluaran perbulan untuk transportasi. Willingness To Pay (WTP) yaitu kemauan atau keinginan penumpang pengguna jasa untuk membayar biaya pada jasa yang telah diperolehnya. Penyebab-penyebab yang berpengaruh bagi (WTP) diantaranya kualitas dan kuantitas. Seperti kepuasan penumpang terhadap angkutan umum dan dari penghasilan pengguna jasa. Dalam menetapkan tarif/tiket angkutan orang atau barang dengan transportasi udara perlu membandingkan kesanggupan dan kesediaan dari pengguna jasa trasnportasi udara untuk membayar biaya bagi pelayanan jasa yang telah diberikan. Guna untuk meningkatkan aktivitas penerbangan yang ada di Bandar Udara Kediri, maka dilakukan penelitihan dan studi ATP dan WTP

\section{Metode}

Berikut adalah langkah-langkah penelitian Anality To Pay (ATP) dan Willingness To Pay (WTP) pada Bandar Udara Kediri, Kabupaten Kediri :

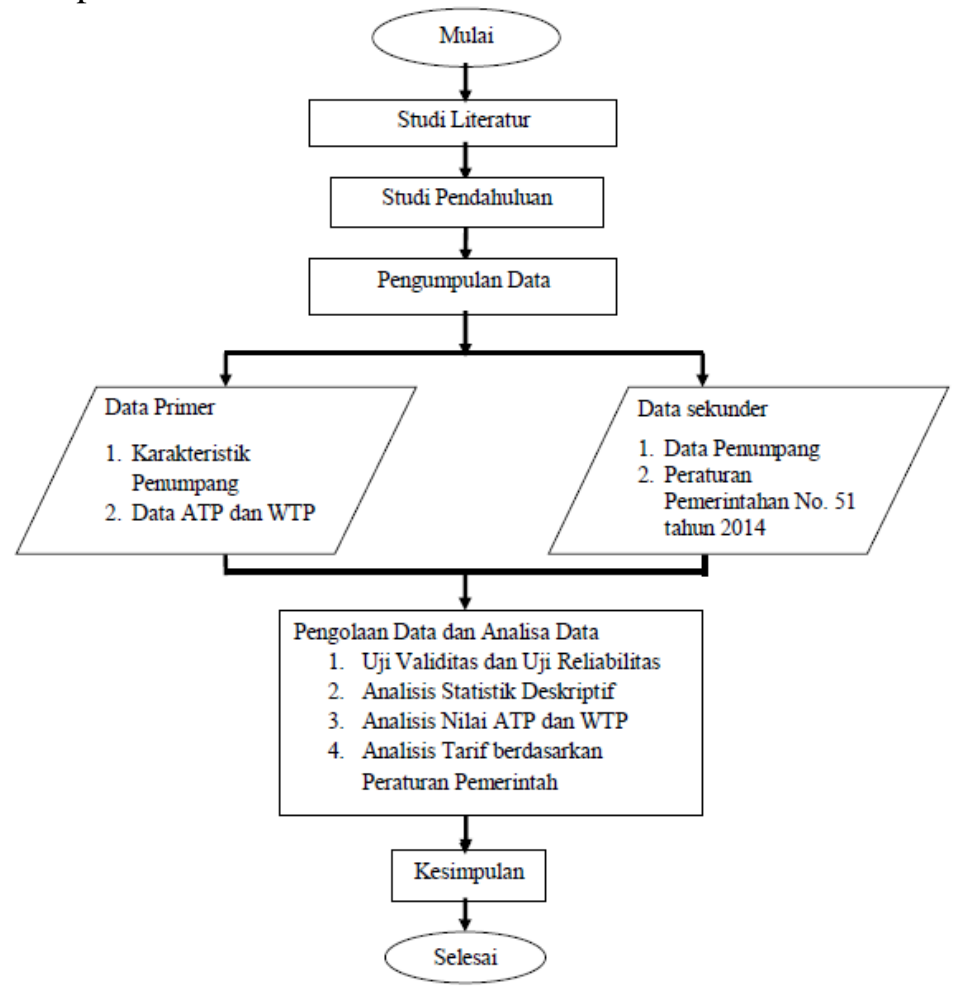

Gambar 1. Prosedur Penelitian 


\section{Hasil dan Pembahasan}

\section{Karakteristik Calon Penumpang}

Analisis karakteristik Calon Penumpang Bandara Kediri diambil di Terminal Tamanan dan Stasiun Kediri terdiri dari beberapa pertanyaan dan dihitung untuk frekuensinya sebagai berikut:

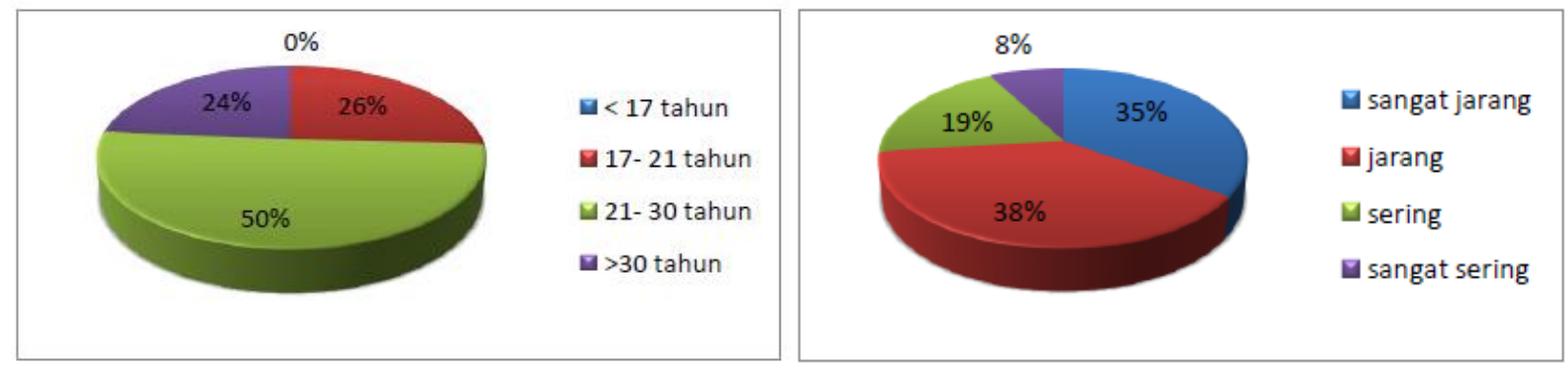

Gambar 2. Usia dan Karakteristik Perjalanan

Berdasarkan data yang diperoleh di atas bahwa dapat disimpulkan responden yang paling banyak berumur 21-30 tahun sebesar 50\%. Dikarenakan rata-rata responden yang melakukan perjalanan dari Kediri-Jakarta yaitu responden yang masih produktif, atau rata-rata masih menempuh Pendidikan. Karakteristik responden diperoleh bahwa 38\% dari 90 responden jarang melakukan perjalanan dari Kediri-Jakarta, responden yang jarang melakukan perjalanan dari Kediri-Jakarta biasanya hanya beberapa kali bepergian bertujuan Jakarta.
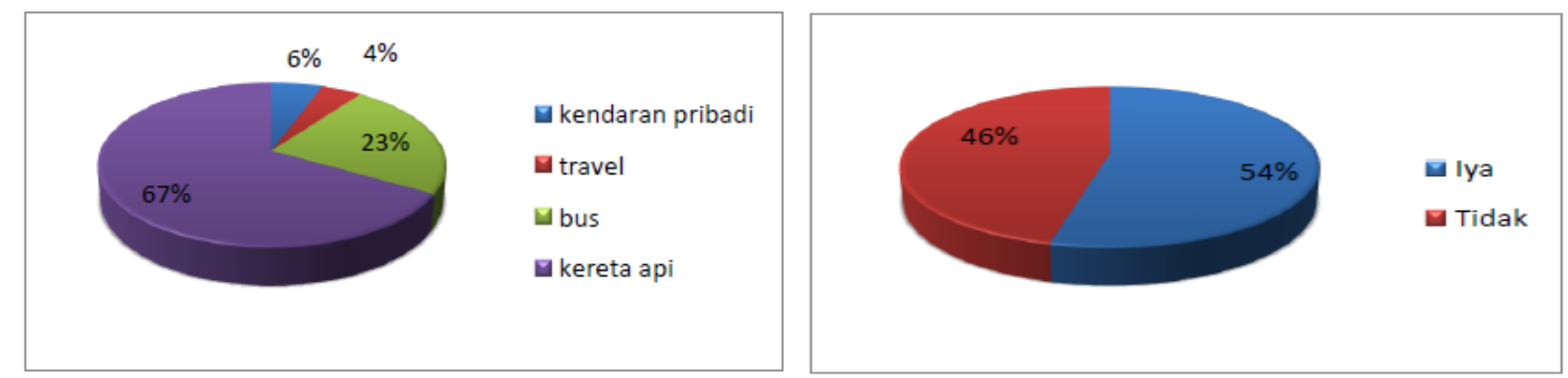

Gambar 3. Transportasi yang sering digunakan dan Pengetahuan akan dibangun Bandara Kediri Berdasarkan data hasil survey dan analisis deskriptif dapat disimpulkan bahwa tranportasi yang sering digunakan terbanyak yaitu Kereta Api sebesar 67\%. Kereta api banyak diminati oleh responden dikarenakan dari fasilitas cukup nyaman, untuk pemberhentian dan pengangkutan penumpang juga kereta api sudah ada jalurnya. Dari 90 responden yang mengisi kuisioner setengah dari responden sudah banyak mengetahui bahaannya ada pembangunan Bandar Udara Kediri yang dibangun oleh PT Gudang Garam dan PT Angkasa Pura 1 (Persero)

\section{Analisis Ability To Pay (ATP)}

Menurut, Tamin, dkk., 1999, metode dan runtutan analisis ATP (Ability To Pay) didasarkan pada rencana pengeluaran biaya untuk transportasi dari pendapatan yang diterima, dengan kata lain ATP adalah kesanggupan masyarakat untuk mampu dalam membayar ongkos perjalanan yang dilakukannya dalam kesehariannya atau rutinitasnya. Beberapa faktor yang mempengaruhi ATP diantaranya besar hasil yag diterima, kebutuhan transportasi total biaya transportasi, intensitas dalam rutinitas perjalanan, konsumtif keseluruhan total per bulan, jenis kegiatan, dan persentase penghasilan yang digunakan untuk biaya transportasi. Analisis Ability To Pay (ATP) terdiri dari rata-rata perbulan responden, persen alokasi untuk biaya transportasi, jumlah anggota keluarga, lama perjalanan dari tempat tinggal ke Terminal Tamanan, Frekuensi Perjalanan dan tujuan perjalanan [5]. 


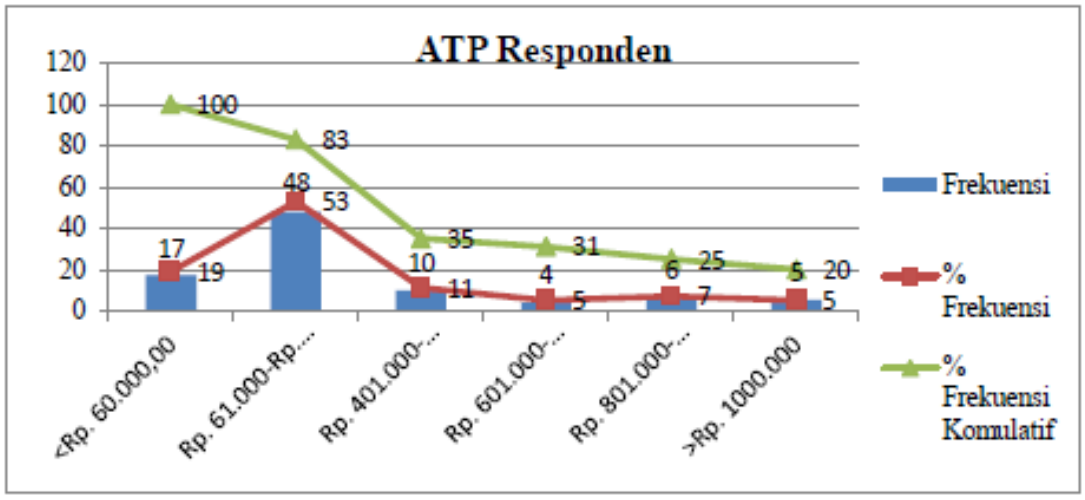

Gambar 4. ATP Responden

Tabel 1. Presentase Kumulatif ATP

\begin{tabular}{|c|c|c|c|}
\hline ATP Responden & Frekuensi & $\begin{array}{c}\% \\
\text { Frekuensi }\end{array}$ & $\begin{array}{c}\% \text { Frekuensi } \\
\text { Komulatif }\end{array}$ \\
\hline$<$ Rp. $60.000,00$ & 17 & $19 \%$ & $100 \%$ \\
\hline Rp. 61.000-Rp. 400.000 & 48 & $53 \%$ & $83 \%$ \\
\hline Rp. 401.000-Rp. 600.000 & 10 & $11 \%$ & $35 \%$ \\
\hline Rp. 601.000-Rp. 800.000 & 4 & $5 \%$ & $31 \%$ \\
\hline Rp. 801.000-Rp. 1000.000 & 6 & $7 \%$ & $25 \%$ \\
\hline$>$ Rp. 1000.000 & 5 & $5 \%$ & $20 \%$ \\
\hline
\end{tabular}

Berdasarkan analisis Tabel 1 dan Gambar 4, Jika tarif penerbangan Bandar Udara Kediri rute KediriJakarta di tetapkan sebesar Rp.401.000 - Rp.600.000 maka kemampuan responden membayar sebesar 35\%, dan jika di tetapkan sebesar Rp.601.000 - Rp.800.000 maka kemampuan membayar responden sebebsar $31 \%$.

\section{Analisis Willingness To Pay (WTP)}

Menurut Tamin. et.al 1999, suatu sistem digunakan dalam analisis WTP didasarkan pada pemikiran pengguna terhadap tarif layanan dari jasa angkutan umum tersebut. Beberapa faktor yang mempengaruhi WTP diantaranya produktifitas jasa angkutan yang disediakan oleh pengusaha, kualitas dan kuantitas pelayanan yang diberikan pengusaha, utilitas pengguna terhadap angkutan umum tersebut, dan penghasilan pengguna [5]. Analisis Willingness To Pay (WTP) adalah nilai rata- rata tarif yang ideal bagi responden untuk tarif Bandar Udara Kediri dengan rute Kediri-Jakarta.

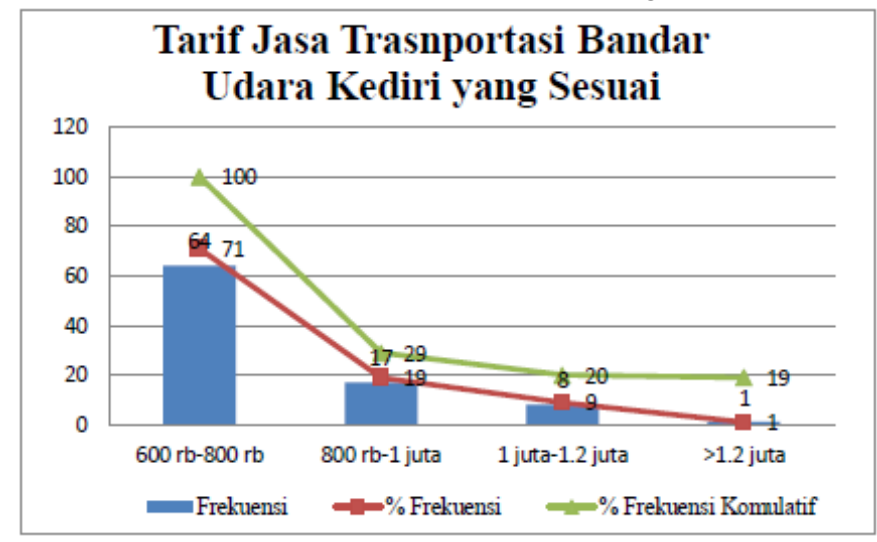

Gambar 5. Tarif yang Sesuai Menurut Responden 
Tabel 2. Tarif Jasa Transportasi Bandar Udara Kediri yang Sesuai Menurut Pendapat Responden

\begin{tabular}{|c|c|c|c|}
\hline $\begin{array}{c}\text { Tarif Jasa Transportasi } \\
\text { Bandar Udara Kediri yang } \\
\text { Sesuai }\end{array}$ & Frekuensi & \%Frekuensi & $\begin{array}{c}\text { \%Frekuensi } \\
\text { Komulatif }\end{array}$ \\
\hline $600 \mathrm{rb}-800 \mathrm{rb}$ & 64 & $71 \%$ & $100 \%$ \\
\hline $800 \mathrm{rb}-1$ juta & 17 & $19 \%$ & $29 \%$ \\
\hline 1 juta-1.2 juta & 8 & $9 \%$ & $20 \%$ \\
\hline$>1.2$ juta & 1 & $1 \%$ & $19 \%$ \\
\hline
\end{tabular}

Tarif Tiket Jasa Transportasi Udara di Bandar Udara Kediri dengan Rute Kediri-Jakarta yeng sesuai menurut pendapat responden dari hasil kuisioner yaitu 600rb-800rb sebesar 71\%.

Hasil rata-rata Willingness To Pay (WTP) kemauan responden untuk membayar harga tiket pesawat di Bandar Udara Kediri Rute Kediri - Jakarta menurut responden adalah Rp.784.000,00.

\section{Penentuan Tarif Berdasarkan Peraturan Pemerintah}

Pada peraturan pemerintah No.51 Tahun 2014 dapat dihitung Tarif jasa transportasi Bandar Udara Kediri menggunakan jarak KM-Penumpang, jarak antara Kediri-Jakarta yaitu sejauh 611,55 km menggunakan titik koordinat [4].

Tarif perhitungan Pada pesawat Propeller dengan dengan kapasitas duduk 30 tempat duduk yaitu:

611,55 x 2,699 = Rp. $1.650 .573,45$

Tarif perhitungan pada pesawat jet yaitu:

$611,55 \times 1,970=$ Rp. $1.204 .753,50$

Namun kemauan responden untuk membayar jasa Transportasi Bandar Udara hanya sebesar Rp. 785.000,00 maka nantinya di ajukan subsidi ke pemerintah untuk menutup biaya pada tarif yang telah ditentukan.

\section{Kesimpulan}

Berdasarkan data-data penelitian yang telah didapat dan sudah diolah dan dianalisis, maka dapat ditarik kesimpulan berikut ini:

a. Karakteristik responden Jasa Transportasi Bandar Udara Kediri, untuk usia yaitu rata-rata 21-30 tahun sebesar 50\%, untuk karakteristik perjalanannya jarang melakukan perjalanan Kediri-Jakarta sebesar 38\%, transportasi yang sering digunakan untuk melakukan perjalanan Kediri-Jakarta yaitu Kereta Api sebesar 67\%, dan untuk pengetahuan akan pembangunana Bandar Udara di kediri sebesar 54\% responden sudah mengetahui.

b. Nilai dari ATP sebesar Rp. 361.000,00 lebih kecil dari WTP sebesar Rp. 784.000,00, kondisi ini disebut Captive Riders atau pengguna memiliki penghasilan yang cukup rendah tetapi utilitas terhadap jasa transportasi cukup rendah.

c. Nilai tarif pada perhitungan dengan menggunakan perturan pemerintah No.51 tahun 2014 dengan menggunakan jarak KM-Penumpang mendapatkan hasil untuk pesawat Propeller dengan kapasits tempat duduk 30 penumpang yaitu sebesar Rp. 1.650.573,45 dan untuk pesawat jet yaitu sebesar Rp. 1.204.753,50. Dan tarif yang sesuai untuk transportasi udara menurut pendapat dari responden yaitu Rp 600.000-Rp. 800.000 


\section{Referensi}

[1] Badan Pusat Statistik Kabupaten Kediri. 2020. Kabupaten Kediri Dalam Angka 2020. Kediri: Badan Pusat Statistik Kabupaten Kediri.

[2] Badan Pusat Statistik Kota Kediri.(2020). Kota Kediri Dalam Angka 2020. Kediri: Badan Pusat Statistik Kota Kediri.

[3] Nasution, M. N.(2008). Manajemen Tranportasi, Galia Indonesia, Jakarta.

[4] Peraturan Menteri Perhubungan Republik Indonesia Nomor 51 Tahunn 2014 Tentang Mekanisme Formulasi Perhitungan dan Penetapan Tarif Batas Atas Penumpang Pelayanan Kelas Ekonomi Angkutan Udara Niaga Berjadwal Dalam Negeri.

[5] Tamin, O.Z. at al (1999) Evaluasi Tarif Angkutan Umun dan Analisis Ability To Pay (ATP) dan Willingness To Pay (WTP) di DKI Jakarta, Jurnal Tranportasi, Forum Studi antar Perguruan Tinggi (FTSP) Jurusan Teknik Sipil Institut Teknologi Bandung, Bandung [6] B. Blesvid, Yelmida, and Zultinar, "Perengkahan Katalitik Palm Fatty Acid Distillate ( PFAD ) Menjadi Biofuel Dengan Katalis Abu TKS Variasi Temperatur dan Berat Katalis," J. Rekayasa Kim. dan Lingkung., vol. vol 10 No, pp. 1-6, 2013. 